\title{
Evaluation of Prospect and Challenges of Cashless Policy. The Case of Commercial Banks in Nigeria
}

https://doi.org/10.21272/fmir.2(4).92-100.2018

\section{Zekeri Abu}

Department of Business Administration, Kwara State University, Malete Nigeria

\section{Kadiri Ismaila Bolarinwa}

Department of Business Administration, University of Ilorin Nigeria

\section{Kowo Solomon Akpoviroro}

$\mathrm{PhD}$, Department of Business and Entrepreneurship, Kwara State University, Malete Nigeria

\begin{abstract}
This paper examines the impact of Cashless Policy on the Performance of Commercial Banks in Nigeria. Structured questionnaire was used to source the primary data. The population of the study was made up of the commercial banks in operation in Nigeria. The population was the 210 management staffs of the eight (8) commercial banks in operation in Lagos Metropolis, Lagos. The study adopted a survey method. The entire population of Questionnaire was administered to the population of the study but 184 questionnaires were dully returned. Data was analyzed using interferential and descriptive statistics. The inferential statistics involve regression, Analysis of Variance (ANOVA) and multiple regression analysis. A pilot study was also used to test the quality, clarity, time scale and bias of the questionnaire. The paper concluded that cash-less policy will impact positively on the fortunes of banks even though some of the charges are not wholly their revenue. It was also discovered that some charges like COT, over-the- counter charges etc. which are associated with a cash-based economy will be a thing of the past. The study recommend that power and electricity infrastructures should be put in place to provide support for electronic banking equipment and care must be taken to ensure that e-money does not compete with demand deposit.
\end{abstract}

Keywords: Cashless Policy, Cash based economy, Commercial Banks, Point of Sales (POS) card acceptance services, Cash-less economy.

\section{JEL Classification: G21.}

Cite as: Zekeri Abu, Kadiri Ismaila Bolarinwa. (2018). Evaluation of Prospect and Challenges of Cashless Policy. The Case of Commercial Banks in Nigeria, Financial Markets, Institutions and Risks, 2(4), 92-100. https://doi.org/10.21272/fmir.2(4).92-100.2018

(C) The Authors, 2018. This article is published with open access at Sumy State University.

\section{Introduction}

There has been a consistent agreement in the body of extant literatures. Akintaro (2017), Ndifan \& Okpa (2014), Babalola (2016) and Daasi, (2016) that small and medium scale enterprises have the tendency to improve the economy of any nation through job creation. Increased flow of finance in the economy calls for policy formulation and implementation that will enhance its growth and performance. However, the recent introduction of cashless policy by the central bank of Nigeria (CBN) has relegated small and medium scale enterprises to a characterization of what is described as the declining glory of the sector. This is evident in small and medium scale enterprises performance, growth and operation, especially in the rural areas of Nigeria, If banks are to open their doors for business transactions to their customers such as traders, market men and women, artisans, schools, churches etc (domestic and international customers) then they must have cash to meet customers' demands on a continuous basis (Ikpefan and Ehimare 2017). Akintaro (2017) there is an optimal use of information technology, no country can attain a speedy social- economic. The future of all business, particularly those in the services industry lies in information technology. In fact, information technology has been changing the ways companies and banks compete. Information technology is more than computers. It encompasses the data a business creates and uses, as well as a wide spectrum of increasing convergent and linked technologies that process such data. Information technology thus relates to the application of technical processes in the communication of data.(Muyiwa et al 2013) The cashless policy was conceptualized by the apex bank to migrate Nigeria's economy from cash based economy to a cashless one 
through electronic payment system, not only to enable Nigeria monetary system be in line with international best practices or discourage movement of cash manually, but at the same time increase the proficiency of Nigeria's payment system which will in turn improve the quality of service being offered to the banking public. Cashless policy aims to curb some of the negative consequences associated with the high usage of physical cash in the economy, including high cost of cash, high risk of using cash, high subsidy, informal economy, inefficiency and corruption (CBN,2011).The introduction of the policy in Nigeria therefore brings up issues that touch on security, privacy, crime and computerization

\subsection{Statements of the Research Problem}

The cashless initiative is an alternative to cash transactions through electronic means using information and communications technology (ICT). Ndifon and Okpa (2014) maintain that the future of all business, particularly those in the service industry lies in information technology. This technology as far as cashless policy is concerned is not only computer. Information technology for banks takes different forms; computerization of customers' accounts information storage and retrieval; deposit and withdrawal through Automated Teller Machines (ATMs); and networking to facilitate access to accounts from any branch of the bank, bio-metrics, use of mobile phones to consummate transactions, internet, and websites. However, transaction made using these innovative products are accounting for an increasing proportion of the volume and values of domestic and cross border retails transaction. Currency and notes are converted into data which are transmitted through telephone lines and satellite transporters (Ovia 2002). These new financial services through electronic medium have caused substantial reduction in transaction costs and ease of transfer of funds.

The study seeks to answer the research question: Is there a significant relationship between Point of Sales (POS) card acceptance services stakeholders and part of banks' income in cash-less economy?

\section{Literature Review}

\subsection{Concept of Cashless Policy}

Nelson (2015) noted that a cashless economy is an environment in which money is spent without being physically carried from one place to another. Electronic devices as means of information that reveal how much a person has deposited and has spent are needed. Acha et al (2016) Information technology plays an important role in bringing about sustainable development in every nation. Without an optimal use of information technology, no country can attain a speedy social- economic growth and development. The future of all business particularly those in the services industry lies in information technology. In fact, information technology has been changing the ways companies and banks compete. According to Morufu and Taibat (2015), Cashless policy is defined as "one in which there are assumed to be no transaction frictions that can be reduced through the use of money balances, and that accordingly provide a reason for holding such balances even when they earn rate of return". Onoh (2017) expressed the difficulty in rightly defining the electronic money but agree that it blends technological and economic characteristics. Daisi (2016) emphasized that Cashless policy does not mean a total elimination of cash, as money will continue to be a means of exchange for goods and services in the foreseeable future. It is a financial environment that minimizes the use of physical cash by providing alternative channels for making payments. Contrary to what is suggestive of the term, cashless economy does not refer to an outright absence of cash transactions in the economic setting, but one which the amount of cash-based transactions are reduced to the barest minimum(Wali,2013

\subsubsection{Benefits of Cashless Economy}

$>$ Echekoba and Ezu (2012), in a research carried out in Nigeria, observed that $68.2 \%$ of the respondents complained about long queues in the bank, 28.9\% complained of bad attitude of tellers (cashiers) while $2.89 \%$ complained of long distance of bank locations to their home or work places. Experts have pointed out specific areas in which the cashless economy will improve the quality of life. These include: Faster transactions reducing queues at points of sales, increased sales, collection of payment is simplified - time spent on collecting, counting and sorting cash is eliminated. Furthermore, excessive of cash outside the formal economy, which is the hallmark of cash based economy, may hinder the effort of monetary policy in managing inflation thus discouraging economic growth (Ikpefan \& Efianmare 2017)

$>$ There is no room for quarrelsome attitude of cashiers in e-transactions. Ndifon and Okpa (2014), opine that the aim of cashless policy is to eliminate the unhealthy consequences associated with the high usage of physical cash which consists of corruption, robbery, leakages and money laundering and other cash-related fraudulent activities. When there is accident as a result of fire or flooding, additional financial loss may be 
sustained due to over reliance and holding of cash for transactions. Cashless economy improves tax collection system; reduces cash handling charges and affects economic development positively. Hence, Osazevbaru and Yomere (2015), opine that the operation of the cash based system has been at a significant cost to the Nigerian economy.

Cashless policy is also beneficial to government as it aids monetary authorities in monetary policy management by reducing stock of money outside the banking system. The consequential effect of this is that it improves monetary policy efficiency, helps control inflation and hence stabilizes the economy (Acha et al., 2016).

$>$ Cobb (2015) pointed out that"electronic payments can thus lower transaction costs stimulate higher consumption and GDP, increase government efficiency, boost financial intermediation and improve financial transparency". She further added that "Governments play a critically important role in creating an environment in which these benefits can be achieved in a way that is consistent with their own economic development plans".

Some researchers maintain that cashless policy reduces transfer/processing fees, improves processing/ transaction time, offers multiple payment options and gives immediate notification on all transactions on customers' account (Ndifon and Okpa, 2014; Osazevbaru and Yomere, 2015). Central Bank of Nigeria (2015) added that the policy is beneficial to the banks and merchants because it enhances large customer coverage, internationalization of products and services, promotion and branding, increases customer satisfaction and personalized relationship with customers, and eases documentation and transaction tracking.

\subsubsection{Problems of Cashless Economy}

Akhalumeh and Ohiokha (2011) observed some challenges with the introduction of cashless policy and their findings show that $34.0 \%$ of the respondents cited problem of internet fraud, $15.5 \%$ cited problem of limited POS/ATM, 19.6\% cited problem of illiteracy and 30.9\% stayed neutral. While in some quarters there was fear of unemployment, some believe it will create more jobs especially when companies manufacturing POS machine are sited in Nigeria.

$>$ Due to the political, social and economic conditions of the country, this policy is not without its constraints. The change from cash based economy to cashless economy moved people away from their comfort zone. This discomfort and the lack of clarity and understanding, Central Bank of Nigeria (2015) said, had hampered the adoption and fueled conspiracy theories amongst stakeholders. Hence CBN maintains that lack of understanding of cash policy amongst the banked and unbanked, resistance due to prevailing cash culture, "Techno -phobia, illiteracy, entrenched poverty (can't spend what you don't have), infrastructure lag, distrust in banking system, lack of clarity in communicating content of policy and inadequate payment terminal service providers (PTSPs) capacity among others are challenges that hinder the effectiveness of cashless policy in the country

Many people in the country lack banking culture as a result they save by crude and informal means, while some lack access to banking services; for such people, e- transaction is a mere story. For many Nigerians the skill and knowledge of information technology is still on the low side thereby making the use of electronic payment options both scary and challenging with negative implications for the adoption of cashless policy (Acha, 2016)

$>$ Nigeria generally suffers from epileptic power supply and inadequacy of electronic-based infrastructures; e-payment cannot function without these. There are some parts of the country that have never enjoyed electricity, others experience frequent power interruptions. Cashless economy is electronic economy; most of the transactions are done electronically. As a result of poor or no power supply in the country, information technology cannot be available; this is a heavy obstacle to cashless economy. To compound this, Nigerians are used to cash transactions and they are finding it difficult to change to cashless economy.

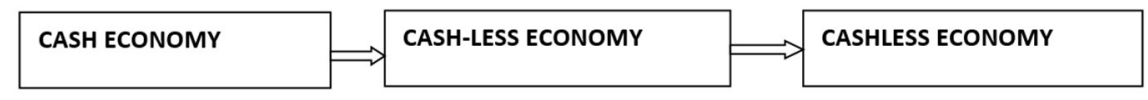

Figure 1. Conceptual Framework of Cashless Policy

Source: Prepared by the author. 
From the illustration above, Odior and Banuso (2012) argued that Nigeria just left the real cash economy to cash-less economy where there is still conglomeration of cash handling and electronic means in the economy and with time move to cashless economy where every transaction or most of the transactions in the economy will be done without physical cash. This is a proof of the new policy of $\mathrm{CBN}$, which state that 'the new policy on cash-based transactions (withdrawals \& deposits) in banks, aims at reducing (NOT ELIMINATING) the amount of physical cash (coins and notes) circulating in the economy, and encouraging more electronic-based transactions (payments for goods, services, transfers, etc.) (CBN, 2011).

\subsection{Theoretical Framework}

German economist Georg Friedrich List $(1789-1846)$, who is regarded as the forefather of the German historical school of economics, stated that economies of the temperate zone will go through four stages of economic development namely - pastoral life; agriculture; agriculture and manufacturing; and manufacturing, agriculture, and commerce. Another German economist, Bruno Hildebrand (1812 - 1878), took a variant yet historical approach to the study of the stages of economic growth and development. He asserted that the key to understanding the stages of economic growth was to be found in the conditions of exchange; thus, he posited three economic stages based on barter, money, and credit. This assertion is known as the Theory of the Monetary Stages of Development and forms the subject matter of this paper. Hildebrand's theory of monetary stages of development explained that an economy would develop along three stages of the mediums of exchange namely - barter, money, and credit.

According to Hildebrand (1878) referred to the natural economy where goods were exchanged directly for other goods. The money exchange system meant that goods and services were exchanged in coinage, which was the principal form of money at the time, in the form of the two precious metals - gold and silver (hence, the gold and silver standards of the late 19th and early 20th centuries). The ultimate transition to the credit economy meant the use of paper money and paper transfers such that wage earners at the time could access credit for property purchases on account of promissory paper notes. As another economist aptly describes: Hildebrand's vision of society [was one of...] advancing from barter to monetary exchange before reaching its highest synthesis in a credit economy [where the] property-less wage earner [could have] access to capital and thereby resolve one of modern society's most pressing problems... Although Hildebrand eventually failed to develop a coherent system of economics, his vision of a barter-money-credit advancement model of economic development provides theoretical evidence of the existing relationship (or correlation) between the mediums of exchange and economic development. The study was anchored upon the Theory of Money which has its roots in the 16th century during which classical economists such as Jean Bold in at that time sought to know the cause of the increases in French prices. He concluded that, among other factors, increases in gold and silver which served as currencies were responsible for the rise in the demand for French-made goods, hence French prices, thus linking movements in prices to movements in money stock. By the 1690s, the quantity theory of money was further advanced by John Locke to examine the effects of money on trade, the role of interest rate and demand for money in the economy (Omanukwue, 2010). In particular, the role of money as a medium of exchange to facilitate trade transactions was born. Economists at the time inferred that the quantum of money needed for such transactions would depend on the velocity of money in circulation and the relationship between the demand from and supply of money such that where there was excess demand over supply interest rates rose and vice versa (Cantillon, 1755; Locke 1692 as cited in Ajuzie, et al, 2008

\subsection{Empirical Literature}

Looking at empirical issues, however, in a cashless economy, money demand equation can be derived without influencing output and inflation (Gali et al, 2016). In this case, money plays the role of a unit of account and the amount of real money balances follows residually after output, inflation and interest rate have been determined

2.3.1. Empirical Evidence From Developed Economy. In examining the cost implications of cashless banking instruments, Gresvik and Owre (2016) studied how much it costs Norwegian banks to process various payment instruments. It finds that payment cards used for cash withdrawals at ATMs cost considerably more since the transactions involve cash replenishment, maintenance and security costs. In addition, the cost of using cheques for cash withdrawals was found to be three times more expensive than cash withdrawals at ATMs. Cross country studies such as Humphrey et al (2016) analyzed patterns in the use of cash and other epayment instruments in 14 developed countries, including the US. Whilst treating payment instruments as if they were traditional goods, the authors construct measures of the cost (analogous to prices) of various 
payment methods in order to study whether differences in cashless instrument usage across countries can be explained by differences in the relative prices of such instruments. The result showed that such price differences failed to determine the usage of e-banking instruments. In other words, the convenience of using a particular instrument - a factor that is not measured may outweigh the price differences that users face (Carrow and Staten, 2000.Similarly, Snellman, Vesala and Humphrey (2015) in their study pointed epayments as any payment service that makes use of information and communications technologies including Integrated Circuit (IC) cards, cryptography and telecommunications. However, in this study, e-payment refers to delivery multichannel that provides for electronic exchange of monetary substances without physical contact of the transacting parties. It includes all electronic transactions as well as e-cheque payment. Epayment provides means of transacting business and settling financial commitment electronically without necessarily touching cash in a cashless society. Hasan, Renzis and Schmiedel (2014) who explored fundamental relationship between electronic retail payment and overall economic growth using data from across 27 European markets over the period 1995-2009 and found that migration to efficient electronic retail payment stimulates overall economic growth, consumption and trade Newstead (2015) examined cashless payments and economic growth and found a link between cashless payment and the pace of economic growth. The study revealed that cashless payment volumes are growing twice as fast in developing economies as they are across the world. Similarly, World Payments Reports (2014) explored the state and evolution of global non-cash payments and found that non-cash payments make it easier and quicker for people and businesses to buy goods and services, pumping money into the system faster and contributing to GDP. Zandi et al. (2017) examine risk perception of the E-Payment Systems using adult consumers in Malaysia and found that e-payment systems impact negatively on firm's sales growth; also their further found that Epayment system has positive influence on consumers purchase intentions.

2.3.2. Empirical Evidence from Nigeria. Okoye and Ezejiofor (2017) examined the significant benefits and essential elements of cashless policy, and the extent to which it can enhance the growth of financial stability in the country. The descriptive research design was adopted for the study with a sample size of 68 questionnaires arrived at using the convenience sampling technique. The data collected was subjected to face validity test, and was tested with ANOVA and chi - square (x2) technique and the results indicate that: majority of Nigerians are already aware of the policy and majority agree that the policy will help fight against corruption/money laundering and reduce the risk of carrying cash. Major problems envisaged to hamper the implementation of the policy are cyber fraud and illiteracy. Based on the findings, they recommended that government should adopt a different strategy to educate the non-literate Nigerians about the cashless economy; and a framework should be worked out to provide cyber security in Nigeria. Ebipanipre \& Uyuoyo (2017) in an article titled analysis of value creation of electronic banking in Nigeria examined trends of banking habit in Nigeria across banking regimes of regulation and deregulation hinged on historical perspective of banking development in Nigeria, from independence to 2012. Relevant secondary data covering 1960 to 2010 were collected from Central Bank of Nigeria annual reports and analysed using the descriptive trend analysis. Their finding suggests a static behavior across the monetary policy regimes and thus cautioned rushing the cashless program until measures are in place to encourage and push fast the banking culture change for the success of the cashless Nigeria program. In a like manner. Osazevbaru and Yomere (2015) explored the benefits and challenges of the cashless policy vis-à-vis the cash based policy. Specifically, Osazevbaru and Yomere (2015) seek whether other Point of Sales card acceptance services stakeholders attract a significant part of banks' income in cash-less economy. To address this, secondary data were collected and content analysis applied in data analysis. After factoring in other POS stakeholders share of income, the study found banks'income higher in cash-less setting than in cash based arrangement. Thus, the cash-less policy offers immense benefits to the banking sector (Osazevbaru and Yomere, 2015) concluded. Ajayi \& Ojo (2016) indicates that the electronic system of payment has a great implication in cashless economy of Nigerian but that it will lead to significant decrease in deposit mobilization and credit extension by Nigerian deposit money banks. They concluded that cashless system of payment need to be examined and the epayment system developed, so that people will get used to it before talking of cashless economy. This is because; bulk of the Nigerian economy is driven by SME and petty traders. To retain this policy of cashless economy in Nigeria, the authors recommended that the migration of our payments system towards a cashless society would require some reforms and a lot of effort and sensitization especially for low income group, who are currently deeply rooted in using cash and see it as a convenient and easy way of receiving and making payments. Oyewole (2015) empirically studied the impact of mobile banking on service delivery in the Nigerian Commercial Banks through the use of questionnaire. He found out that the introduction of e-banking services has improved banking efficiency in rendering services to customer. His findings showed that mobile 
banking improved banks service delivery in a form of transactional convenience, saving of time, quick transaction alert and saving of service cost which has recuperate customer's relationship and satisfaction. Olatokun and Igbinedion (2015) investigated the adoption of ATM in Nigeria. They found out that constraints such as relative advantage, complexity, observability, and compatibility and trial ability were positively related to attitude to the use of ATM cards in Nigeria. James (2017) investigated the acceptance of e-banking in Nigeria. The result showed that acceptance of e-banking in Nigeria was significantly influenced by age, educational background, income, perceived benefits, perceived ease of use, perceived risk and perceived enjoyment. James (2017) used Rogers Diffusion of Innovation theory to investigate the determinants of the adoption of mobile banking in Nigeria. The study empirically showed that age, educational qualification, relative advantage, complexity, compatibility, observability and trialability were important determinants of the adoption of mobile banking. This therefore makes it imperative for relevant stakeholders to make efforts to positively influence these independent variables so as to make mobile banking more popular. Morufu and Taibat (2015) used qualitative survey to ascertain bankers' perceptions of electronic banking in Nigeria. The results suggest that bankers in Nigeria perceive electronic banking as a tool for minimizing inconvenience, reducing transaction costs, altering customers' queuing pattern and saving customers banking time. Muyiwa (2017) examined the effect of cashless policy in Nigeria and his study found that cashless banking has positive and significant effect on national development; also his study revealed that cashless policy has positive impact on employment regime in Nigeria supported by (Akhalumeh \& Ohiokha, 2015). Moses \& Ashike (2015) used consumer acceptance theory to investigate customers' perception of security indicators (SI) in online banking sites in Benin, Nigeria. He found out that SI were not very effective at alerting and shielding users from revealing sensitive information to fool e-banking sites in Nigeria. Following the aforementioned gap created by the earlier researchers in the light of mixed views in findings and conclusion reached by different researchers, this study will aim at filling the gap by introducing a profound and clearer variables and analysis on the effect of central bank of Nigeria (CBN) cashless policy on the development Small and medium scale enterprises in Nigeria. Okoye \& Ezeifor (2017) looked at the challenges, benefits and prospects of cashless policy and their study found that some of the challenges that has the capacity to hamper the success of cashless policy are lack of electricity power supply and poor information technology infrastructure to mention but a few. On the other hand, their study revealed that cashless policy will promote economic growth and provide banks with more liquidity for lending to needy sectors and contribute to eliminating corruption if the right infrastructure and trust is instituted. Muyiwa et al. (2013) found that the introduction of cashless policy will contribute in reducing robbery incidences; attraction of more foreign directs investment and creation of employment.

\section{Methodology}

Structured questionnaire was used to source the primary data; the researcher followed a sequence of logical steps to develop a good questionnaire that would accomplish the research objective. Questions were formulated to obtain the needed information; the questionnaire was scrutinized in order to prove it validity and meeting the required standard, in view of this, it was overhauled by four (4) senior lecturers of Kwara State University Nigeria for omissions and ambiguity. The population of the study was made up of the commercial banks in operation in Nigeria. The population was further narrowed down to an accessible population due to factors that might inhibit the success of the search objective. On the foregoing the population was now the eight (8) commercial banks in operation in Lagos Metropolis, Lagos State:

Access Bank Nig Plc, Union Bank of Nig. Plc,

United Bank for Africa (UBA),

Zenith Bank Plc,

First Bank of Nig. Plc,

Diamond Bank Plc,

Ecobank Nig. Plc,

Guaranty Trust Bank Plc,

Wema Bank Plc,

These are the commercial banks (eight) 8 in Lagos Metropolis. The study adopted a survey method. The entire population of the management staffs of the eight Banks is 210 staffs. Questionnaire was administered to the 
population of the study but 184 questionnaires were dully returned. Data was analyzed using interferential and descriptive statistics. The inferential statistics involve regression, Analysis of Variance (ANOVA) and multiple regression analysis. A pilot study was also be used to test the quality, clarity, time scale and bias of the questionnaire as pointed by Naoum (2002).

\section{Data Presentation, Analysis and Discussion of Findings}

\subsection{Test of Hypothesis}

\section{Hypothesis}

Ho: There is no significant relationship between Point of Sales (POS) card acceptance services stakeholders and part of banks' income in cash-less economy.

Table 1. Relationship between Point of Sales (POS) card acceptance services stakeholders

\begin{tabular}{|c|c|c|c|c|}
\hline Model & $\mathrm{R}$ & R Square & Adjusted R Square & $\begin{array}{c}\text { Std.Error of the } \\
\text { Estimate }\end{array}$ \\
\hline 1 & $.781^{\mathrm{a}}$ & .609 & .601 & .417 \\
\hline
\end{tabular}

Source: Authors computation, 2017.

a. Predictors:(constant) POS card acceptance services stakeholders

b. Dependent Variable: part of banks' income in cash-less economy.

$\mathrm{R}^{2}$ value of 0.609 reveals that Point of sales card acceptance services stakeholders independently accounts for $60.9 \%$ of the variation in part of banks' income in cash-less economy thereby accepting the alternative hypothesis and rejecting the null hypothesis.

Table 2. ANOVAa

\begin{tabular}{|c|c|c|c|c|c|}
\hline Model & Sum of squares & Df & Mean Square & F & Sig. \\
\hline Regression & .510 & 2 & .510 & 7.111 & $.000^{\mathrm{b}}$ \\
\hline Residual & 17.161 & 182 & .242 & & \\
\hline Total & 17.671 & 184 & & & \\
\hline
\end{tabular}

Source: Authors computation, 2017

a. Predictors :( constant): POS card acceptance services stakeholders

b. Dependent Variable: part of banks' income in cash-less economy.

The $f$ - statistics of 7.111 shows that the model is statistically significant.it shows that there is a significant relationship between Point of Sales card acceptance services stakeholders and part of banks' income in cashless economy

\subsection{Discussion of Findings}

It is clear that the estimated income of banks in a cash-based economy is lower than the income of banks in cash-less economy. Therefore, the null hypothesis that, other POS card acceptance services stakeholders will attract significant part of banks' income in cash-less economy, thereby eroding significantly the benefits of the policy is rejected. Thus, given that banks are not entitled to 100 percent of POS charges (the POS charges is share among different stakeholders), they will be more profitable in a cash-less setting than a cash Payment Channels Transaction Volume. In sum, the cash-less policy will bring immense benefits to the banks which will translate to improved services for customers and impacts positively on other stakeholders in the financial services sector. On the long-run, the entire economy will also benefit. There will be no COT (meaning that there will be no charges from ATM, OTC, and Cheque payment channels); but the POS charges and Web (internet banking) charges will still be applicable. Therefore, charges as sources of income to banks will majorly come from POS and Web channels. With the Nigerian banking industry still smarting from the global economic meltdown few years ago and the insolvency, failures and mismanagement that resulted in the recent Mergers and Acquisitions (M\&As), the sector needs tighter control that will engender customer satisfaction and spur economic growth But this makes special precautions economically appealing and expedient. We are, however, concerned that while this cashless policy has its noble intentions with the ultimate aim of growing our economy and encouraging the emergence of e-payment across the country, the groundwork for the takeoff of the system has not been sufficiently done 


\section{Conclusion}

This paper has shown that cash-less policy will impact positively on the fortunes of banks even though some of the charges are not wholly their revenue. It was also discovered that some charges like COT, over-thecounter charges etc. which are associated with a cash-based economy will be a thing of the past. The unbanked will become banked, thereby increasing the customer base of banks. With reduction in the volume of cash in circulation, this will avail banks more deposits to do their businesses which will impact positively on their profits. Also, the cost of banks' operations will considerably reduce. For e- banking to have an effective application in Nigeria, the regulating agencies must set a beddy eye on the movement of the real variables. It is worthy of note that if the one of the primary purposes for which the cashless banking paradigm is introduced, which is to increase vault cash by discouraging the volume of quasi-money and cash in circulation are not achieved there may be an adverse impact of informal income growth on money supply. On the foregoing electric banking has been adopted to a large extent in the Nigerian banking industry. It has affected deposits taking, cash withdrawals, money transfers, loan administration; the provision of banking services in several ways, these include quick data processing and retrieval of information increased customers satisfaction, quick customer service delivery and production of accurate and reliable information, faster access to capital, reduced revenue leakage and reduced cash handling costs.

\section{Recommendations}

The cash-less policy should however not been seen as having no consequences. For instance, the use of POS in cash-less setting will attract special charges that do not go with cash transactions. To mitigate the challenges of the cash-less policy the study recommended as follows:

$>$ That power and electricity infrastructures should be put in place to provide support for electronic banking equipment. Situations where banks have to provide own power supply practically every working day (like the banks in Rural environs) will increase overhead costs and diminish the gains accruable to them. Legal and regulatory framework that will check electronic fraud should be put in place by the government.

$>$ Hence care must be taken to ensure that e-money does not compete with demand deposit which still from the basis for credit creation in most developing economies like Nigeria and e-money must to a significant extent replace time deposits. This achievement depends largely on the measures being put in place to ensure that A Critical Analysis of Cashless Banking Policy in Nigeria.

$>$ The credit creation process which operates via the multiplication of deposits can be boosted to the extent to that e-money replaces time deposits and the extent to which demand deposits are substitute for e-money.

\section{References}

1. Acha, I. A., Ikoh, I. and Nsien, C. (2016). The efficacy of Nigeria monetary policy: A comparative analysis. Scholedge International Journal of Business Policy and Governance, 3(4): 51-62.

2. Akhalumeh, P.B \& Ohiokha, F. (2015). Nigeria's Cashless Economy: the Imperatives. International Journal of Management and Business Studies, 2 (2), 31-36.

3. Ajayi, S. I. and O. O. Ojo (2016), Money and Banking: Analysis and Policy in the Nigerian Context, Second Edition, University of Ibadan, Daily Graphics Nigeria Ltd.

4. Babalola, R. (2016). E-payment: Towards a cashless economy", a keynote address of the finance minister of state at card expo Africa conference. http://www.nigeriavillagesquare.com Central Bank of Nigeria Cash-less Nigeria.

5. Banker's Committees Resolution on the use of ATM and others. Central Bank of Nigeria (2012). Towards a cashless Nigeria: Tools and Strategies. NSC 24th National Conference, July, pp.1-30

6. Carow, K. A. and M. E. Staten (2000, -Plastic Choices: Consumer Usage of BankCards Vs Proprietary Credit Cardsll, Working Study, April

7. Central Bank of Nigeria (2011), Money Market Indicators \& Money and Credit Statistics, CBN Statistical Bulletin,

8. CBN Publications Central Bank of Nigeria Website (2011), - New Cash Policy, Presentation for the Interactive Engagement Session with Stakeholders on Cash-Less Lagos, Stakeholder Session Supermarket Operators

9. Central Bank of Nigeria (2011). Towards a cashless Nigeria: Tools \& strategies. Nigerian Journal of Economy, 3(2): 344-50.

10. Central Bank of Nigeria, (2012). Toward a cashless Nigeria: Tool and strategiesll, retrieved from 
11. Central Bank of Nigeria, (2011). Guidelines on Point of Sales (POS) Card Acceptance Servicesll, retrieved from www.cenbank.org

12. Central Bank of Nigeria, (2011). New cash policyll, retrieved from www.cenbank.org

13. Cobb, A. (2015). http://www.ameinfo.com/50050.html Echekoba, Daasi, G.L.K. (2016). Traditional financial institutions and rural enterprises in Ogoni land of Rivers state. Unpublished seminar paper, Department of Economics, University of Uyo, Uyo - Nigeria.

14. Ebipanipre, G. M. \& Uyouyo, K.O. (2017). An empirical analysis of the benefits of cashless economy on Nigeria's economic development, Research journal of finance and accounting, 4(17), 11-16.

15. James, A. O. (2017). The Acceptance of e-banking by customers in Nigeria: World Review of Business Research, 2(2), 6-8

16. Morufu, O. and Taibat, A. (2015). Bankers perceptions of electronic banking in Nigeria: A review of post consolidation experience. Research Journal of Finance and Accounting, 3(2): 5-6.

17. Muyiwa, O., Tunmibi, S., \& John-Dewole, A.T. (2017). The Impact of Cashless Economy in Nigeria. Greener Journal of Internet, Information \& Communication Systems, 1(2), 40-43.

18. Ndifon, E. and Okpa, I. (2014). Challenges and benefits of the cash-less policy implementation in the Nigerian economy. European Journal of Business and Management, 6(26): 24-32.

19. Newstead, S. (2015). Cashless Payment Underpins Economic Growth. Retrieved Odumeru, J. A (2015), "Going Cashless: Adoption of Mobile Banking in Nigeria". Arabian Journal of Business and Management Review (Nigerian Chapter) Vol. 1, No. 2, 9-17. NG_VOL_1_2/2.pdf. on 13th June 2014

20. Okoye, P.V.C and Ezejiofor, R. (2017), "An Appraisal of Cashless Economy Policy in Development of Nigerian Economy". Research Journal of Finance and Accounting, Vol.4, No.7, pp237-252

21. Onoh, J. K. (2017). Dimensions of Nigeria's monetary and fiscal policies: Domestic and external.: Astral Meridian Publishers: Aba.

22. Osazevbaru, H. O. and Yomere, G. O. (2015). Benefits and challenges of Nigeria's cashless policy. Kuwait Chapter of Arabian Journal of Business and Management Review, 4(9): 1-10.

23. Oyewole et al. (2015). Electronic Payment Systems and Economic Growth: A Review of Transaction to Cashless Economy in Nigeria. International Journal of Scientific Engineering and Technology, 2(9), 913919.

24. Oyewole, O. S., Gambo, E. J., Abba, M. and Onuh, M. E. (2015). Electronic payment system and economic growth: A review of transition to cashless economy in Nigeria. International Journal of Scientific Engineering and Technology, 2(9): 913-18.

25. Oyewole OS, El-Maude JG, Abba M, Onuh ME. (2015). Electronic payment system and economic growth: a review of transition to cashless economy in Nigeria. Int J Sci Eng Technol 2:913-918. 